\title{
Czech chartists claim two died in nuclear accident
}

Charter-77, the Czechoslovak human rights movement. last week entered the nuclear debate, with an exposé of conditions at the Jaslovske Bohunice power station. According to Document 22 of the Charter movement (distributed abroad by the Palach press), employees at the power station have been compelled (under threat of loss of premium payments) to expose themselves to radiation levels considerably above the safety standards, while, in the course of the last three years, two serious accidents, one of them causing the death of two workers, have taken place at the station. Indeed, claim the Chartists, since the second accident in February, 1977, the station is still "temporarily" closed.

The Jaslovske Bohunice power station has a long and chequered history. It was constructed under the terms of the Soviet-Czechoslovak general agreement for nuclear energy cooperation of April 1955. In 1956, it was predicted that the station would be commissioned in "about 1962" - in fact, it went critical in 1972 and became fully operational the following year.

According to Dr Frantisek Janouch, who at that time was working at the Czechoslovak Institute of Nuclear Research, and who took part in the many professional and organisational discussions relating to the construction of the reactor, the project was essentially a Soviet proposal and was carried out under Soviet supervision. The station uses a $110 \mathrm{MW}$ gas-cooled heavy-water reactor. According to Dr Janouch, the Russians wanted to see if it was possible to construct an effective reactor of this type-leaving the details to be worked out by the Czechs and done at Czech cost.

In 1969, before the Jaslovske Bohunice station, known as the $\mathrm{A}-1$, was completed, the Czechoslovak nuclear energy industry was switched, following a Soviet "recommendation", to lightwater pressure reactors of the VVER type, for which the Soviet Union would supply "a substantial part of the main equipment". Whether this change of plan affected the final stages of work on the A-1 is not clear; it appears, however, from the Chartists' report that the projected automatic system for mounting new fuel elements was never brought into operation, and the mounting was done manually. Workers on the reactor were, says the report, "under psychological stress", often working a 16-hour shift instead of the six hours or less customary in "developed" countries. On 5 January, 1976, an error occurred in the mounting process. The element shot out of the reactor, under a pressure of 60 atmospheres together with a large quantity of radioactive $\mathrm{CO}$. Since the emergency gas-traps and filters were insufficient for an accident of this magnitude, radioactive gas escaped into the atmosphere. In the area of the accident, emergency evacuation plans went into operation; unfortunately, one escape door had been locked, apparently to reduce petty thefts, and two workers were suffocated.

Some six weeks later, however, disaster struck again (according to the Chartists). During the mounting of new fuel cells, the primary circuit overheated, the air-tight seal of the steam generator ruptured, and, as a result, the primary circuit, part of the secondary circuit and the working area all became contaminated. Radioactive material entered the drainage system of the plant and a stream in the vicinity has since had to be "fenced off" as contaminated.

During the repair work to the reactor, says the Chartists' document, safety levels of radiation were increasingly ignored, in an attempt to expedite the work.

The anonymous authors of the document urge nothing less than an open discussion and local referenda as to whether nuclear power stations should be constructed at all. This is all the more remarkable since uranium is Czechoslovakia's sole native energy source of any magnitude, and current plans evisage a nuclear expansion of $10.280 \mathrm{MW}$ over the next 15 years, so that by 1990 over $30 \%$ of the installed generating capacity will be nuclear.

With such a major commitment to nuclear energy, the reaction of the Czechoslovak authorities to the report is predictably to deny everything. No such accidents occurred, they say, and even if they had occurred, they were under no obligation to make any public announcement.

Vera Rich

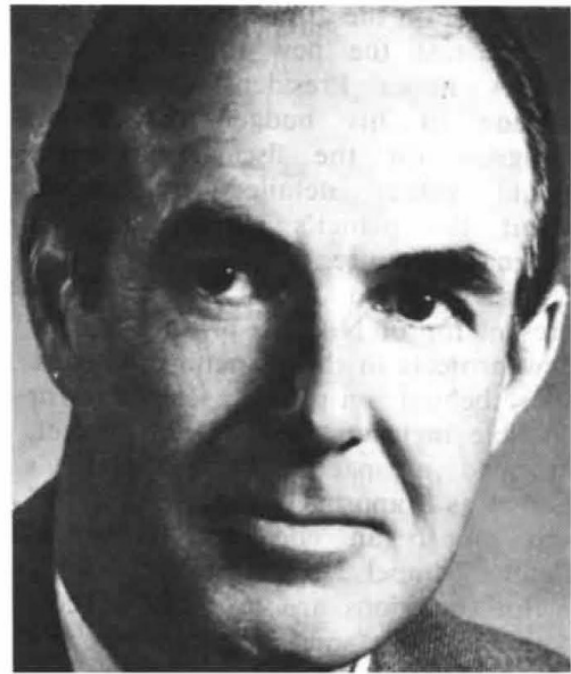

Alastair W. Gillespie

a new investment tax credit of $25 \%$ on all R\&D expenditure; for other firms, the basic rate of the R\&D investment tax credit will be doubled from 5 to $10 \%$.

The Government's declared commitment to increase R\&D support have 